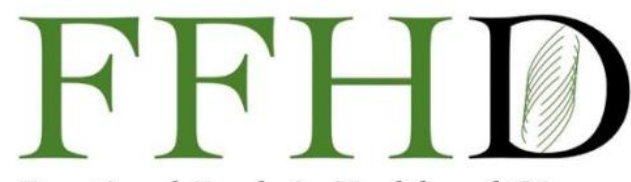

Functional Foods in Health and Disease

\title{
Review on physicochemical, medicinal and nutraceutical properties of poppy seeds: a potential functional food ingredient
}

\section{Aleem Muhammad ${ }^{1}$, Aqsa Akhtar ${ }^{2}$, Sadia Aslam², Rao Sanaullah Khan², Zaheer Ahmed ${ }^{3}$, Nauman Khalid ${ }^{2 *}$}

${ }^{1}$ Punjab Food Authority, Lahore, Pakistan; ${ }^{2}$ School of Food and Agricultural Sciences, University of Management and Technology, Lahore, Pakistan; ${ }^{3}$ Department of Home and Health Sciences, Allama Iqbal Open University, Islamabad, Pakistan

*Corresponding Author. Nauman Khalid, PhD, School of Food and Agricultural Sciences, University of Management and Technology, Lahore, Pakistan

Submission Date: August 13 ${ }^{\text {th }}, 2021$; Acceptance Date: October $7^{\text {th }}, 2021$; Publication Date: October $13^{\text {th }}, 2021$

Please cite this as: Muhammad A., Akhtar A., Aslam S., Khan R.S., Ahmed Z., Khalid N. Review on physicochemical, medicinal and nutraceutical properties of poppy seeds: a potential functional food ingredient. Functional Foods in Health and Disease 2021. 11(10): 522-547. DOI: https://www.doi.org/10.31989/ffhd.v11i10.836

\section{ABSTRACT}

The poppy seed plant (Papaver somniferum L.) is well known for its health benefits. It contains plenty of nutrients including proteins, oil content, dietary fiber, antioxidants, tocopherols and other micronutrients. It is also under exploration considering its in vitro bioactive potential against various health issues such as hypertension, pain and cancer. Poppy is mainly grown for its opium and oil contents; however, poppy seeds are also widely used for cooking purposes. Poppy seeds contain various essential bioactive compounds including alkaloids, flavonoids, phenolic compounds and polyunsaturated fatty acids that can be effectively used as food ingredients in various applications. Poppyseed oil is considered a good quality oil owing to its rich polyunsaturated fatty acid content. Thus, tremendous potential exists in poppy seeds to be used as functional food ingredients and nutraceutical agents in various formulations. Medicinal and functional uses of poppy seed have been discussed, including some aspects of the utilization of the poppy seeds in the food industry. Further research is required to bring out its ingredient potential in food and health supplements. 


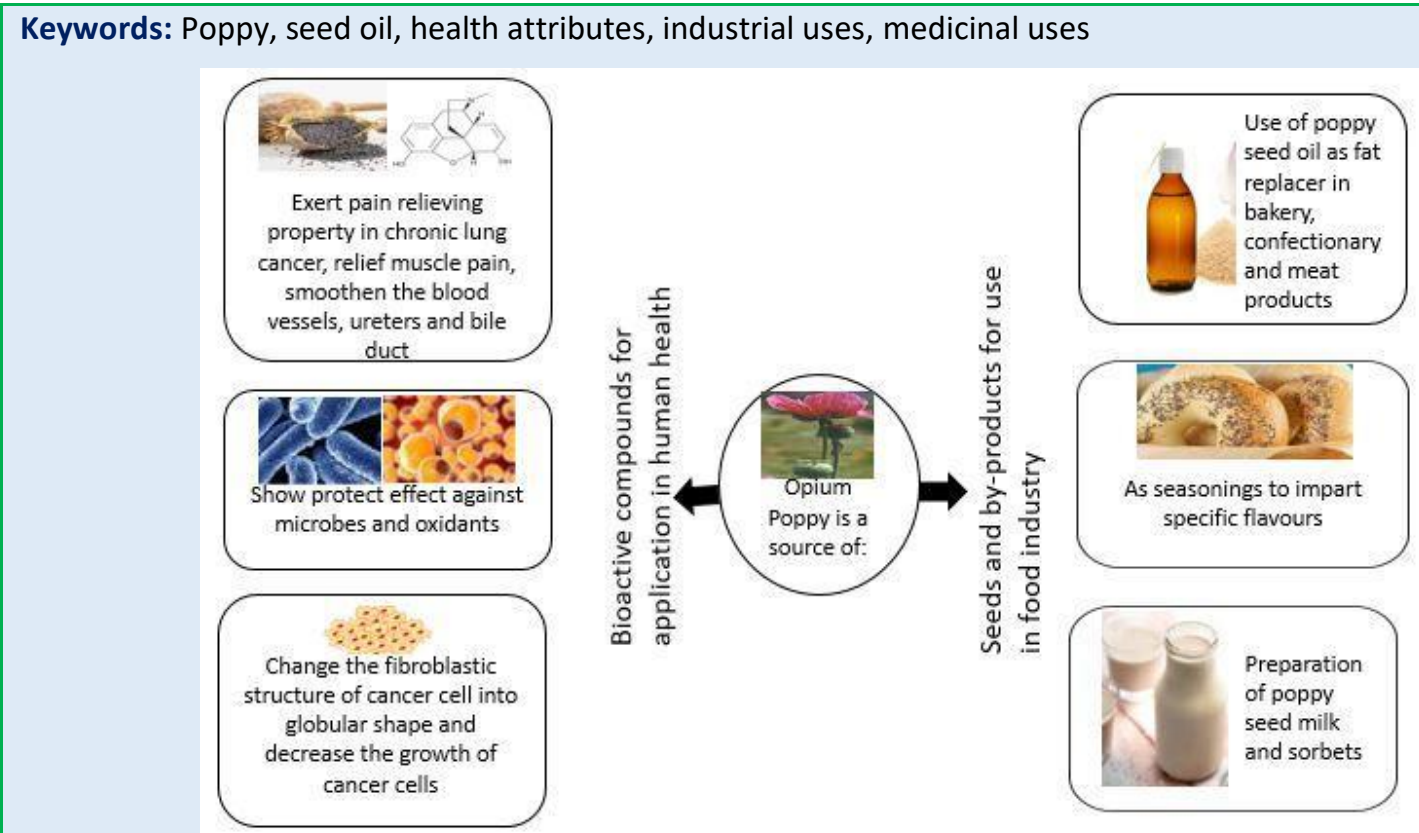

CFFC 2021. This is an Open Access article distributed under the terms of the Creative Commons Attribution 4.0 License (http://creativecommons.org/licenses/by/4.0)

\section{INTRODUCTION}

A surge for better and natural food ingredients has occurred with the advancement in food science and technology knowledge. There have been many new novel ingredients that are gaining attention that were previously ignored. One of such kinds is the poppy plant belonging to the family of Papaveraceae. The poppy plant is usually grown for its opium content and seed oil worldwide. Opium is the source of alkaloids used in pharmaceutics. However, poppy seeds do not contain opium content, so it has been explored as a food material. Traditionally poppy seeds were used as a food ingredient in curries, bread, sweets, and confectionery products. Protein and oil contents of poppy seeds varied between 21.5-23.5\% and $46.2-49.4 \%$ respectively [1]. The most striking feature of this plant is the abundance of polyunsaturated fatty acids in its seed oil [2]. The poppy seed oil contains a good quantity of $\beta$ tocopherol (309.5-567.3ppm) and the main fatty acids include stearic, palmitic, oleic, linoleic and linolenic acid. Poppy seeds and oil possess high nutritional value that are recommended for utilization in food products as functional food ingredients [3].

Research findings and applications of poppy seed in the food industry have been limited due to multiple reasons. One of such reasons has been the ban on its cultivation in various parts of the world due to its use in narcotics and addictions [4]. This restriction has discouraged research scientists to work on it. Hence literature does not contain an adequate body of knowledge on this potential source for food and medicine. The ban on poppy seed cultivation was lifted in 1974 and controlled production of the poppy plant was allowed under the license system. Poppy seeds are separated from the capsules under inspection and the whole yield of capsules is purchased by the government. Poppy seeds can be utilized in the food industry as it contains an appreciable amount of oil and protein content [5]. Prevention of the accidental 
consumption of morphine and especially the illegal extraction of morphine to produce heroin from common commercial poppy seeds is challenging owing to lack of access to rapid techniques to distinguish between food and pharmaceutical varieties [6]. Opium poppy remains the main commercial natural source of drugs such as codeine, morphine, along with a variety of semi-synthetic products, including oxycodone and buprenorphine, which are mainly derived from thebaine [7]. Poppy is generally divided into three categories: industrial, when grown to extract alkaloids from the capsule; culinary, when grown for seeds and oil; both industrial and culinary, when the capsules and seeds are used to extract alkaloids as well as to collect seeds. Another useful dimension of the poppy plant comes in through its decorative use in some countries [8].

This review is designed to gather all available data on this plant and discuss its nutritional potential as a natural functional food ingredient. The objective of this review is to provide a comprehensive overview of poppy seeds including their nutritional and nutraceutical benefits. This review covers the chemical composition, functional properties and health benefits of poppy seeds and their utilization in different food products.

Cultivation Regions Varieties: The area under opium poppy cultivation is about $270,000-300,000$ hectares throughout the world. The five major countries involved in the cultivation of poppy are India, Burma, Turkey, Afghanistan and Russian states [9]. Due to the illegal and unauthorized use of opium poppy, the United Nations has banned the growth and cultivation of Papaver somniferum in countries including Iran, India, Turkey, Bulgaria, Greece, Yugoslavia and Russia [10].

Three main varieties of Papaver somniferum are cultivated in Asia. A poppy plant that has white flowers and seeds is cultivated in India and it is known as the variety album. The poppy plant which has purple flowers and gray seeds is cultivated in Europe and is designated as the variety nigrum. The poppy, recognized for its purple flowers and purplish-black seeds, is majorly cultivated in Asian countries and is known by the different name as labrum [11]. The poppy seeds which are used mainly for food purposes have low alkaloid content, higher seed yield and the flower color may be blue to blue-grey or sometimes they are white [12].

The opium poppy has been used to produce three types of plants: narcotic varieties, oilseeds / spices, and ornamental plants. Virtually all poppies have some opiates, so growing the plants, either as food or as legitimate drugs is strictly controlled. The raw opium is the hardened milky sap of the green fruit. Dried latex is made from green capsules and is used for both medical purposes and illegal narcotics. Opium is a mixture of many components, including the alkaloids morphine and codeine commonly used as analgesics and cough suppressants. Traditionally, it is obtained by cutting into the almost ripe poppy seed capsules between 10 and 20 days after flowering. Codeine is a component of more than $22 \%$ of pain reliever supplements in the United States. Papaverine is a smooth muscle relaxant and vasodilator while sanguinarine is antimicrobial and anti-inflammatory. The poppy has been used as a sedative and pain reliever for millennia [13].

Poppy seeds are usually used for culinary purposes. $40-60 \%$ of the weight of opium poppy seeds is oil, and the plant is commonly cultivated as a source of edible and industrial oil. Poppy oil is pale yellow in color, fixed, tasteless, oily, and useful as salad oil because it is less prone to rancidity than olive oil. The oil is also used to make margarine and salad dressings and is used as a cooking oil. The seed meal that is left over from the seeds after the oil is pressed is a good source of high-quality protein that could 
potentially be used in making functional foods. Poppy seed oil is high in unsaturated oleic and linoleic acids and, therefore, potentially useful as a food source supplement [13].

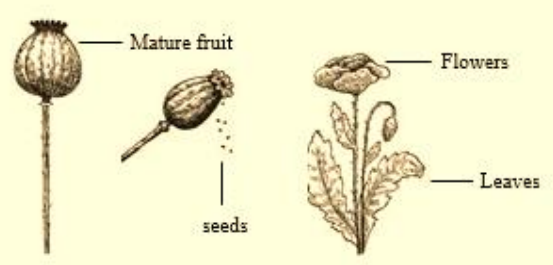

Figure 1. Opium poppy (Papaver somniferum) with mature fruit and seed (left) and flower and leaves (right).

Chemical Composition and Nutritional Profile: The poppy plant is an oilseed crop and oilseed crops are a major source of many beneficial nutrients including fats, proteins and carbohydrates with some bioactive compounds, which may act as an important ingredient for nutraceuticals and functional food products [14]. Poppy plants also contain sugars, latex, wax, gums, meconic acid, lactic acid, and alkaloids i.e., morphine, codeine, noscapine, papaverine and thebaine. The seeds are said to contain essential nutrients, minerals, organic compounds, and enzymes. The poppy seed oil is rich in unsaturated fatty acids and tocopherol contents. Poppy oilseed does not have narcotic properties, so it is also used in infant formulas nowadays due to its nutritional importance. Many food products of oilseed crops are now available as nutraceutical supplements in the market due to the presence of valuable compounds such as tocopherols and phytochemicals [15].

The results of a quantitative estimation of nutrients of Papaver somniferum were carried through compositional analysis in different studies. The poppy seed has 3.4-5.3\% moisture content, the average amount of crude protein, crude fat, crude fiber and total ash content in poppy seeds has been reported as $11.9-23.5 \%, 32.44-46.2 \%, 6.2-30.1 \%$ and $0.5-6.6 \%$ respectively $[2,3,16-18]$.

The results of a study showed a great variation among the composition of three different colored Turkish poppy seed varieties. The blue-colored seed variety has the highest oil content $(46.30 \%)$ as compared to yellow-colored seed (38.91\%) and white-colored seed (36.07\%). Among all three of these varieties, the blue-colored seed variety showed the highest moisture (6.40\%) and ash (6.20\%) contents. The highest protein content has been reported in the white-colored seed variety $(21.4 \%)$; this variety also has the highest seed weight and largest size among all the varieties [19].

Amino Acid Profile of Poppy Seed Proteins: Poppy seeds are rich in a varying number of amino acids. Studies indicate that poppy seeds from blue and white varieties of Paperer somniferum are rich in leucine, valine, threonine and lysine [20] \{Peter, 2012 \#4; Eklund, 1975 \#6\}. The proteins of poppy seed from dhawla chotta, dhawla bada and commercial varieties were found rich in aspartic and glutamic acids and arginine [18]. Indian poppy seed commercial varieties contain an appreciable quantity of methionine which is comparable to the FAO reference pattern for this amino acid [18]. The amino acid concentration in different poppy seed varieties is provided in Table 1. 
Table 1: Amino acid profile of different varieties of poppy seeds [13]

\begin{tabular}{|c|c|c|c|c|}
\hline Amino acids & Dhawla Bada [18] & Dhawla Chotta [18] & Commercial Variety [18] & $\begin{array}{l}\text { Indian Poppy Seed } \\
\text { Variety [110] }\end{array}$ \\
\hline & & $\mathrm{g} / 100 \mathrm{~g}$ of Protein & & $(\%)$ \\
\hline Aspartic acid & 9.27 & 10.25 & 9.38 & - \\
\hline Threonine & 4.00 & 3.66 & 3.44 & - \\
\hline Serine & 4.48 & 4.39 & 4.40 & - \\
\hline Glutamic acid & 24.26 & 25.40 & 24.85 & - \\
\hline Proline & 4.20 & 4.37 & 4.50 & - \\
\hline Glycine & 4.19 & 4.46 & 4.06 & - \\
\hline Alanine & 4.03 & 4.32 & 4.46 & - \\
\hline Valine & 5.29 & 5.99 & 5.38 & 7.1 \\
\hline Methionine & 2.66 & 2.54 & 2.67 & 2.3 \\
\hline Isoleucine & 4.50 & 4.35 & 4.43 & - \\
\hline Leucine & 7.22 & 7.99 & 7.65 & - \\
\hline Tyrosine & 4.23 & 4.17 & 3.97 & - \\
\hline Phenylalanine & 5.40 & 4.99 & 4.80 & - \\
\hline Histidine & 2.70 & 2.54 & 3.13 & 2.9 \\
\hline Lysine & 3.51 & 3.48 & 3.57 & 1.5 \\
\hline Arginine & 10.04 & 10.69 & 10.21 & 10.41 \\
\hline Tryptophan & 1.02 & 1.03 & 1.00 & - \\
\hline Threonine & - & - & - & 4.2 \\
\hline
\end{tabular}

Fatty Acid Composition of Poppy Seed Oil: Oil is the important component of poppy seeds and averages between 45-54\% in seeds [5]. Oil poppies are mainly derived from cross-pollination, so this subspecies presents very different morphological characters: the color of the flowers, the seeds, and the shape of the capsules. Poppy oil has an excellent organoleptic property and the low linolenic acid content in its composition delays oxidation and improves shelf stability. The oil is extracted by pressing. Cold pressing yields about $30-35 \%$ of the light-yellow oil, which is used for culinary purposes. Hot pressing at $115^{\circ} \mathrm{C}$ gives the oil a dark yellow or reddish color and is used as a refined product [21].

Fatty acid composition of this oil changes with changing varieties [22]. The fatty acid contents of poppy seed oil contain about $11 \%$ saturated and $89 \%$ unsaturated fatty acids [23]. The major fatty acid present in poppy seed oil is linoleic acid (68\%) [20]. The unsaturated fatty acids in the poppy seed oil are linoleic acid, oleic acid, linolenic acid and palmitoleic acid. The main saturated fatty acids include stearic acid, palmitic acid and arachidic acid. An overview of the fatty acid profile of poppy seed oil from different studies is presented in Table 2. 
Table 2: Fatty acid profile of poppy seed oil based on different studies

\begin{tabular}{|c|c|c|c|c|c|c|c|c|c|c|}
\hline Fatty acids & $\begin{array}{l}\text { Bialek, } \\
\text { Bialek } \\
{[111]}\end{array}$ & $\begin{array}{l}\text { Carrión-Prieto, } \\
\text { Silva Castro } \\
\text { [16] }\end{array}$ & $\begin{array}{l}\text { Lancaricová, } \\
\text { Havrlentová } \\
\text { [112] }\end{array}$ & $\begin{array}{l}\text { Rahimi, } \\
\text { Arslan } \\
\text { [22] }\end{array}$ & $\begin{array}{l}\text { Aksoy } \\
\text { [113] }\end{array}$ & $\begin{array}{l}\text { Midilli, } \\
\text { Bayram } \\
{[23]}\end{array}$ & $\begin{array}{l}\text { Azcan, } \\
\text { Kalender } \\
{[73]}\end{array}$ & $\begin{array}{l}\text { Nergiz, } \\
\text { Ötles } \\
\text { [17] }\end{array}$ & $\begin{array}{l}\text { Hlinková, } \\
\text { Havrlentová } \\
\text { [114] }\end{array}$ & $\begin{array}{l}\text { Luhmer, } \\
\text { Schulze- } \\
\text { Kaysers [37] }\end{array}$ \\
\hline Amount & $(\%)$ & $(\%)$ & (\%) & (\%) & (\%) & (\%) & (\%) & $(\%)$ & (\%) & (\%) \\
\hline $\begin{array}{c}\text { Palmitoleic } \\
\text { acid }\end{array}$ & - & - & - & $0.11-0.25$ & 0.13 & 0.10 & - & 0.15 & $0.33-0.39$ & $1.7-2.0$ \\
\hline Oleic acid & 1.1 & $4-11$ & $16-30$ & $\begin{array}{c}13.30- \\
17.80\end{array}$ & 11.94 & 16.98 & $13.2-36.8$ & 12.83 & $15.39-16.80$ & $11.2-14.9$ \\
\hline $\begin{array}{l}\text { Linoleic } \\
\text { acid }\end{array}$ & 69.3 & 45 & $50-70$ & 72.55 & 74.47 & 71.73 & $41.0-68.0$ & 75.72 & $65.02-65.83$ & $70.7-75.2$ \\
\hline $\begin{array}{l}\text { Linolenic } \\
\text { acid }\end{array}$ & 0.7 & 2.7 & - & $\begin{array}{l}0.55- \\
0.75\end{array}$ & 0.6 & 0.12 & - & 0.43 & $0.60-0.70$ & 0.66 \\
\hline Stearic acid & 13.9 & - & - & $\begin{array}{c}1.84- \\
2.40\end{array}$ & 1.93 & 2.27 & - & 1.81 & 1.86 & - \\
\hline $\begin{array}{l}\text { Palmitic } \\
\text { acid }\end{array}$ & 10.0 & $8.6-10$ & $6-16$ & $\begin{array}{l}7.96- \\
10.19\end{array}$ & 9.79 & 8.74 & $8.9-21.5$ & 8.64 & $15.13-15.55$ & $10.7-12$ \\
\hline $\begin{array}{l}\text { Arachidic } \\
\text { acid }\end{array}$ & 0.1 & - & - & $<0.20 \%$ & - & - & - & 0.37 & $0.07-0.08$ & - \\
\hline
\end{tabular}


A recent study reported the fatty acid composition of three different colored varieties i.e., blue, yellow and white varieties with raw, oven cooked, and microwave cooked seeds. The presence of high linoleic acid content in poppy seed oil makes the oil beneficial for food processing [24]. Ghafoor, Özcan [24] determined the effect of pre-treatment i.e., oven and microwave roasting of poppy seeds on Physicochemical properties and total phenolics, flavonoids, anthocyanin contents and antioxidant activity of poppy seeds and oil. Roasting decreased fatty acid contents including linoleic acid in blue, yellow, and white seeds and its contents were 57.91, 61.91, and $64.83 \%$ in oil from raw seeds and $57.23,60.78$, and $64.11 \%$ in oven-roasted and $56.97,60.08$, and $60.84 \%$ in microwave-roasted seed oil, respectively. Tocopherol and phenolic contents were also significantly reduced in roasted seed oil as compared to raw seed oil.
Micronutrient Composition of Poppy Seed: Poppy seeds have many beneficial major and minor mineral contents. Calcium (1.03-1.45g/100g) and phosphorus $(0.79-0.89 \mathrm{~g} / 100 \mathrm{~g})$ have been found major elements present in poppy seed followed by $\mathrm{Zn}(130 \mathrm{mg} / \mathrm{kg})$, $\mathrm{Mn}(29 \mathrm{mg} / \mathrm{kg}), \mathrm{Cu}(22.9 \mathrm{mg} / \mathrm{kg}), \mathrm{Mg}(15.6 \mathrm{mg} / \mathrm{kg})$ iron $(8.5-11.1 \mathrm{mg} / 100 \mathrm{~g})$ and lodine $(6 \mathrm{mg} / \mathrm{kg})$ [25]. Concentrations of some major and minor mineral contents of poppy seed reported in different studies are presented in Table 3. Poppy seeds sometimes get contaminated with heavy metals which make them dangerous for human consumption. Heavy metals present in poppy seeds include cadmium (0.09-2.3 $\mathrm{mg} / \mathrm{kg})$, lead (0.050-1.5 mg/kg) and chromium (0.020$5.2 \mathrm{mg} / \mathrm{kg}$ ). The contamination of heavy metals in the poppy seeds might be due to some environmental factors [26].

Table 3. Mineral content of poppy seeds based on different research studies

\section{Mineral content $\quad$ Kumaravel and Alagusundaram [29] Azcan, Kalender [73] Nergiz, Ötles [17]}

\begin{tabular}{|lccc|}
\hline Amount & $(\mathrm{mg} / \mathrm{kg})$ & $(\mathrm{mg} / \mathrm{kg})$ & $(\mathrm{mg} / \mathrm{kg})$ \\
\hline Calcium & 690.50 & 1.6 & 14423 \\
\hline Sodium & 81.16 & 50.9 & 11253 \\
\hline Potassium & 746.70 & 5.1 & 319 \\
\hline Phosphorus & 3980.0 & - & 91 \\
\hline Iron & 5.475 & 44.8 & 04 \\
\hline Zinc & 2.575 & 74.5 & 1.6 \\
\hline Copper & 2.581 & - & 20 \\
\hline Magnesium & 287.20 & - & 176 \\
\hline Selenium & 0.0130 & - & - \\
\hline Manganese & 3.848 & & - \\
\hline
\end{tabular}




\section{Phytochemicals In Poppy}

Alkaloids: Alkaloids are chemicals present in opium [27]. Opium has alkaloid contents in the range of 1020\%. There are about 40 individual alkaloids isolated from the opium poppy and five out of them are important, including morphine (8-17\%), codeine (0.7$5 \%)$ thebaine $(0.1-2.5 \%)$, benzylisoquinoline papaverine $(0.5-1.5 \%)$ and phthalide isoquinoline noscapine (1-10\%), commonly known as narcotine [8, 28]. Other alkaloids such as aporphines, protoberberine and tetrahydro protoberberine, rhoeadines, benzophenanthridine and tetrahydroisoquinolines are present in trace amounts [11].

Besides alkaloids, opium poppy also contains neutral elements and organic acids. The neutral elements present in opium are opionin, meconin and meconoidin. Organic acids present in opium are lactic, caffeic, meconic and ferulic acids [28]. The production of alkaloids can be affected by the high zinc and cadmium content in opium poppy. The higher concentration of cadmium in the seed and capsule of the poppy plant induces abiotic stress in the plant. In response of high cadmium content in the poppy plant, the alkaloid production is enhanced [29]. The alkaloids produced in this response are mainly narcotine, morphine and papaverine in capsules. The average amount of major alkaloids of poppy seed are morphine $(3.0-23.0 \mathrm{mg} / \mathrm{kg})$, codeine $(0.3-6.0 \mathrm{mg} / \mathrm{kg})$, thebaine $(0.2-1.0 \mathrm{mg} / \mathrm{kg})$, narcotine $(2.0-12.0 \mathrm{mg} / \mathrm{kg})$, naiceine $(0.1-1.0 \mathrm{mg} / \mathrm{kg})$ and papaverine $(0.5-3.0$ $\mathrm{mg} / \mathrm{kg}$ ) [30]. Another study reported the alkaloid content of poppy seed as Morphine (3.31 mg/kg), codeine $(1.13 \mathrm{mg} / \mathrm{kg})$, narcotine $(0.73 \mathrm{mg} / \mathrm{kg})$ and papaverine $(3.04 \mathrm{mg} / \mathrm{kg}$ ) [30]. López, Pereboom-de Fauw [31] determined the concentration of opium alkaloids in poppy seeds and bakery products using LC-MS/MS. A set of forty-one samples comprising of three white poppy seed samples, thirty-two blue poppy seed samples, three ground blue poppy seed, one poppy seed filling and two bakery products containing poppy seed was collected from Germany and Netherland in 2015. The morphine content of poppy seeds ranged from $0.2 \mathrm{mg} / \mathrm{kg}$ to $240 \mathrm{mg} / \mathrm{kg}$ while $0.1-340 \mathrm{mg} / \mathrm{kg}$ concentration of codeine was detected in poppy seed samples. Thebaine ranged from below $0.1 \mathrm{mg} / \mathrm{kg}$ to $106 \mathrm{mg} / \mathrm{kg}$ in poppy seed samples. Relatively low concentration of morphine content was detected in two poppy seed containing pastries at the level of $0.5 \mathrm{mg} / \mathrm{kg}$ and $0.6 \mathrm{mg} / \mathrm{kg}$ respectively. Traces of thebaine $(0.1 \mathrm{mg} / \mathrm{kg})$ and noscapine $(0.2 \mathrm{mg} / \mathrm{kg})$ were detected in pastry samples enriched with poppy seed.

Morphine is an alkaloid that possesses narcotic and tranquilizer properties. The hypersensitive dose is $60 \mathrm{mg}$ causing renal failure, respiratory depression, and toxicity [32]. Codeine is a natural isomer of methylated morphine, used for its analgesic, cough suppressant and antidiarrheal properties. After the discovery of codeine, many salts of codeine have been prepared such as hydrochloride, phosphate, sulfate, citrate, salicylate codeine, cyclohexenyl ethyl barbiturate, cyclopentenyl allyl barbiturate, diallyl barbiturate and diethyl barbiturate. Codeine is a common cough medicine ingredient and is also marketed with other active ingredients, linctus for many indicated uses, ampoules for subcutaneous use, or intramuscular injection [33]. Papaverine is utilized 
for the vascular and visceral, gastrointestinal tract, bile ducts and ureter, in cerebral and coronary vasodilation, in subarachnoid hemorrhage spasm treatment and the prevention of headache in case of migraine [34]. Noscapine is an opium poppy benzylisoquinoline alkaloid, used primarily for its cough suppressant properties, has also been shown to have anticancer activity, without significant analgesic properties. Currently, noscapine is being investigated for the treatment of different forms of cancer and hypoxic ischemia in stroke patients [33].

Tocopherols and Tocotrienols: Poppy seeds are also important due to the presence of antioxidants like tocopherols and tocotrienols. In the absence of tocopherols and tocotrienols, free radicals are formed in PUFAs thereby causing the oxidation and reduction of the tocopherols and tocotrienol effect [35]. Poppy seed oil is rich in $\gamma$-tocopherol followed by $\alpha$-tocopherol, $\beta$-tocopherol and $\delta$-tocopherol. Different studies have been carried out to estimate the tocopherol content of poppy seed oil. Ekici and Technology [36] reported the $21.13-28.84 \mathrm{mg} / \mathrm{kg} \alpha-$ tocopherol, 236.23-268.1 mg/kg $\beta$-tocopherol, 3.17$12.71 \mathrm{mg} / \mathrm{kg} \delta$-tocopherol and $261.31 \mathrm{mg} / \mathrm{kg} \mathrm{\gamma}$ tocopherol in poppy seed oil. Özcan and Atalay [3]reported the 26.4 - $36.9 \mathrm{mg} / \mathrm{kg}$ a-tocopherol, 309.5-567.3 mg/kg $\beta$-tocopherol and 6.1-17.4 mg/kg $\delta$-tocopherol. Ghafoor, Özcan [24] studied the tocopherol contents of the oven and microwave roasted yellow, blue and white poppy seed varieties and found average values of $23.53-28.84 \mathrm{mg} / \mathrm{kg} \alpha$ tocopherol, 244.3 - $268.1 \mathrm{mg} / \mathrm{kg} \beta$-tocopherol, 6.89 $16.78 \mathrm{mg} / \mathrm{kg} \delta$-tocopherol and 263.7 - $281.5 \mathrm{mg} / \mathrm{kg} \mathrm{\gamma}^{-}$ tocopherol. Luhmer, Schulze-Kaysers [37] found the $\gamma$-tocopherol content of the different varieties ranging from 158 to $330 \mathrm{mg} / \mathrm{kg}$, $\alpha$-tocopherol ranging from 23 to $56 \mathrm{mg} / \mathrm{kg}$ and $\delta$-tocopherol ranging from 3.3-4.5 mg/kg. Rokosik, Dwiecki [38] mentioned the $\alpha$-tocopherol and $\mathrm{y}$-tocopherol $44.4 \mathrm{mg} / \mathrm{kg}$ and 271.6 $\mathrm{mg} / \mathrm{Kg}$ in white poppy and 33.1 and $207.3 \mathrm{mg} / \mathrm{kg}$ in black poppy respectively.

Reviewing the latest research on tocopherols and tocotrienols, undeniable benefits of tocopherols and tocotrienols in protecting against cancer and diseases including cardiovascular, metabolic, autoimmune, bone and neurological disorders have been demonstrated. These compounds are associated with preventing oxidative stress due to their antioxidant properties. $\alpha$-tocotrienol has shown strong activity against lipid oxidation due to a more uniform distribution of tocotrienols in the plasma membrane and more efficient collision of $\alpha$ tocotrienol with radicals [39].

This antioxidant potential of tocotrienol has a lasting impact on overall health. For example, it can offer a significant reduction in thiobarbituric acid reactive substances in patients with hyperlipidemia and carotid stenosis linked to platelet peroxidation. Tocotrienols have also been shown to have the ability to eliminate free radicals that cause DNA damage, thus providing protection especially for older people [40]. Studies on the hypercholesterolemic properties of tocotrienols have gained ground after showing that the addition of tocotrienols significantly reduced cholesterol levels by suppressing the HMG-CoA reductase activity [41]. Since tocopherol is a potent antioxidant, the neuroprotective effects of vitamin $E$ 
are believed to be mediated by its antioxidant property [42]. A flourishing body of knowledge supports the idea that tocotrienol is a potent neuroprotective agent against Alzheimer's disease [43].

Organic Acids and Phenolic Contents: The organic acids present in the opium poppy include lactic acid, caffeic acid, meconic acid and ferulic acid and they are helpful in the treatment of many health-related disorders [28]. It has been observed that the leaves of Papaver rhoeas L. possess remarkable lipophilic and hydrophilic antioxidant activity and a significant concentration of total phenolic contents $(134.8 \pm 0.6$ mg GAE/100 g) and flavonoids (119.0 $\pm 1.4 \mathrm{mg}$ C.E./100 g) [44].

Medicinal Properties of Poppy: In ancient times the poppy plant was mainly used as a drug for its narcotic effect on the human body. The dried capsules of the poppy plants were used to cure colic hypertension. The extract of the poppy plant is mixed with water and this paste is used as tinctures. The extract of the poppy plant is used in many ayurvedic medicines to cure the cough in many Asian countries. In the $19^{\text {th }}$ century, this plant has been used in products that induce various health benefits. In many Asian countries like India and Pakistan people eat or smoke poppy seed extract for the treatment of malaria and constipation [45]. Alkaloids are secondary metabolites that are mostly nitrogenous. These alkaloids have many biological activities; therefore, they are mostly used in pharmaceutical products. They are illegally used in narcotics and are poisonous
[46]. The opium poppy is known as an important medicinal plant since it contains $>80$ alkaloids and is synthesized from its various parts which belong chiefly to phenanthrene and tetrahydrobenzoisoquinoline groups [47]. The major alkaloids known to be of pharmaceutical potential include analgesics like morphine, codeine, antispasmodic and papaverine [48]. These are mainly synthesized in capsules and latex of a mature plant. Benzylisoquinoline alkaloid (BIAs) with prime pharmaceutical importance are present in poppy possessing antimicrobial activity i.e., sanguinarine, the muscle-relaxing activity i.e., papaverine and one having antitussive potential and anticancer activity i.e., noscapine [49].

Nowadays, alkaloids i.e., morphine and codeine extracted from opium poppy latex serve as the main functional ingredients in medicine to serve as pain relievers. As agriculture progressed, the genetically modified opium poppy variety produced a dominant pharmaceutical precursor instead of morphine and codeine. The transgenic poppies in which the alkaloid contents have been modified mainly to produce reticuline instead of morphine and codeine which is a precursor of many pharmaceutically active compounds possessing antibacterial, antimalarial and anticancer potential [50].

Analgesic Effect: There is significant evidence that poppy was used as an analgesic since 3000 BC, despite this old usage of the poppy as a painkiller, it was not earlier than 1905 when German scientist Setuner isolated the main contributing factor towards this analgesic property of poppy as alkaloid morphine 
[51]. Morphine is the most important alkaloid present in the plant and it is also the most effective in reducing pain and the main action is by acting on $G$ Protein-Coupled Receptors (GPCR). Apart from morphine, other alkaloids present in poppy are codeine, thebaine, papaverine and noscapine [27]. Opioids are the most effective agents used in pain therapy. These are known as the golden standards for the relief from acute postoperative pain and are also known to be helpful in the treatment of moderate to severe cancer pain [52]. In a study, it has been reported that pain-related problems can be cured by the application of systemic morphine [53]. Some randomized controlled trials have shown that a sustained releasing of oral morphine is significantly linked with the reduction of chronic lung cancer pain, and the pain-relieving potency was comparable to the efficacy of a well-known trans-dermal fentanyl pain reliever [54].

Opioids have been used for many years as a medicinal drug to prevent acute to severe chronic pains in the human body. It provides relief from many severely painful conditions in the body such as headache, otalgia, toothache, labor pain, kidney and bladder pain [55]. Two major alkaloids of opium poppy morphine and codeine aid in relieving pain. But the use of these alkaloids is restricted in many areas as they act as non-medical drugs [56]. It acts agonistically on the $\mu$-opiate and k-receptors. It acts directly onto the intestine to smoothen the muscles [57]. Thebaine acts synergistically with morphine as it helps in the synthesis of many morphine-like substances which also helps in relieving pain [27]. Morphine in-general and Morphine- 6 beta- glucuronide (a major metabolite of morphine) in particular is shown to be a potent analgesic [58]. Opioid alkaloids are often effectively employed in chronic pain issues ranging from moderate to severe degrees [59]. In a study, it was evidenced that a compound carrying a poppy alkaloid i.e., papaverine hydrochloride was equally effective as sodium diclofenac to reach a short-term relief from acute renal colic pain by administration of a $120 \mathrm{mg}$ intravenous dose [60]. The use of opioids in treating non-cancer chronic pain has increased manifolds [55]. For instance, in the developed world opioids are being utilized to manage non-cancerous and cancerous pain and major professional bodies have developed the prescribing guidelines [61-63].

Lowering Blood Pressures: Papaverine is a poppy alkaloid, which lowers blood pressure and prevents any cardiac attack. Papaverine when ingested acts on the peripheral nervous system in the brain which causes the vasodilation of the peripheral and splanchnic arteries. Poppyseed oil is a rich source of linoleic acid which helps in lowering the serum cholesterol level. In a study, it has been reported that dilation of the peripheral blood vessels in the body results in a lowering of the blood pressure of human beings in standing posture [56].

Antitussive Agents: Antitussive agents help to relieve coughing. Noscapine alkaloid from poppy seeds is used as an antitussive agent [27, 64]. Noscapine, previously known as narcotine, acts as a cough suppressant with codeine and morphine [56]. A variety of poppy plants i.e., corn poppy flower and 
seeds (Papaver rhoeas L.) contain rhoeadic acid, paaveric acids and alkaloid rhoeadine which have proved beneficial remedies for cough, sleep and insomnia [65].

Codeine is also an opium alkaloid that is obtained from partially dried unripe latex of the opium poppy. Opium contains about $0.2-0.3 \%$ of the codeine which acts as an antitussive agent and helps in suppressing coughing. When ingested, it binds to the opiate receptors in the body, reducing the secretions produced by the bronchi and acts on the medulla oblongata to help in curing cough [66]. In different studies, codeine has also been demonstrated as an effective antitussive agent [67, 68]. Codeine has also been generally used as a pain reliever and antitussive agent in cough syrup formulations [69]. The fresh petals of corn poppy are turned into syrup after processing. This syrup is used for the treatment of coughs, colds, bronchial complaints, asthma, and insomnia [70]. Due to its antitussive potential and activity as an anticancer medicine [71], the bio-extraction of noscapine became a subject of renewed interest [7, 49, 72]. Moreover, owing to its manifold potential in therapeutic applications and flexibility to alter, noscapine is an authentic modern drug. Besides its versatility, another astonishing feature of it is its lack of side effects and addiction mechanisms, which distinguishes it from other alkaloids of the opium poppy.

Muscle Relaxation: Papaverine is used to provide relief from muscle pain and smoothen the blood vessels, ureters and bile duct. Morphine imparts its effect on the central nervous system to smoothen the muscles. Morphine acts as a narcotic and its effect on the body might cause addiction, its overdoses tend to slow down breathing and may even cause death. Morphine binds by activating a specific receptor that controls brain functions. Its G-Protein Coupled Receptors bind with GPCR and reduces pain [73]. Two alkaloids of poppy plant cryptopine and protopine decrease contraction of muscles and low doses help to lower the intraocular pressure [28]. Papaverine alkaloid is used in vasodilation because it can bring about smoothening and relaxation of the muscles. It is also used to recover cerebral, peripheral and vascular problems. It acts as an antispasmodic agent to cure gastrointestinal problems. When ingested as a drug in the body it acts and stops the activity of the enzyme phosphodiesterase. As a result, the calcium concentration reduces which, if present, acts as a barrier in muscle contraction and relaxation [66]. The consumption of soporific (sleep-inducing) tea prepared from poppy capsules had also since long been practiced in Europe, perhaps dating back to the start of poppy cultivation [74]. In a study, it has been shown that papaverine, a poppy alkaloid, acts as a smooth muscle relaxant and is used mainly for relieving cerebral and peripheral ischemia linked with arterial spasm and myocardial ischemia issues which are worsened by arrhythmias [75].

Therapeutic Potential (Ayurveda medicine): Some therapeutic value of the opium poppy plant has been described in the ancient records of the Indian medicine system known as Ayurveda. Mainly, purified opium which is in most cases a dried latex obtained from the plant capsule is reported as the main component with therapeutic potential i.e., for the treatment of dysentery, diarrhea, spasms, and pain etc. Although, it is well established that opium contains analgesics including morphine, codeine and thebaine as well therapeutic agents like sanguinarine 
and papaverine etc. The precise molecular basis behind its potential abilities as described in Ayurveda are yet to meet an explanation. Thus, it is one of the requirements for Ayurveda research to carry out future pharmacological research on opium and its alkaloids with therapeutic potential. Nonetheless, currently, pharmaceutical markets are well loaded with certain opium-based Ayurveda formulations [28].

\section{Nutraceutical Properties of Poppy}

Antioxidant and Antibacterial Potential: With time the demand for foods which have antimutagenic, anti-inflammatory, antibacterial and antiviral phenolic compounds have increased. Phenolic compounds act as antioxidants and aid in the reduction of many disorders. These phenolic compounds can neutralize the free radicals produced in body cells. They also capture the free oxygen molecules and help in the decomposition of the peroxides. These free radicals are produced during normal cell metabolism. If they are not treated, they cause damage to biomolecules and have the potential of causing disorders in the body like cancer, diabetes, asthma, inflammatory diseases, cardiac diseases, neural diseases, and premature aging in some human beings [76]. In a study, it was found that poppy contains biologically active compounds such as flavonoid glycosides, phenols and resins, which possess considerable antioxidant, antimicrobial, antiinflammatory and anthelmintic properties and it was suggested in the study that poppy can be used in the treatment of infectious diseases caused by various microbes [77]. In another study of wild poppy, basal leaves have demonstrated the hydrophilic and lipophilic antioxidant activity and the highest total phenolic contents and flavonoids [44]. The antibacterial potential of aqueous extract of poppy was evaluated against both gram-positive and gramnegative bacteria and it was shown that poppy seed extract had significant antibacterial activity against both kinds of bacteria [78].

\section{Anti-cancer and Anti-tumor Activity of Alkaloids of}

Poppy: The poppy plant extracts cause changes in cell morphology by shrinking the cell, damaging the cell production cycle and changing the fibroblastic structure of cancer cells into globular shape and decreasing the growth of cancer cells [79]. It has been reported that the effectiveness of repeated use of morphine at a dose of $5-10 \mathrm{mg} / \mathrm{kg}$ daily for 6 days is efficient to achieve marked reduction in tumor growth and lung metastasis [80].

In a study, noscapine potentiated the anticancer activity of doxorubicin synergistically against TripleNegative Breast Cancer (TNBC) tumors as noscapine showed a dose-dependent reduction in the tumor volumes at a dose of $150-550 \mathrm{mg} / \mathrm{kg} /$ day compared to controls [81]. Another study evaluated the anticancer activity of Noscapine and Gemcitabine Combination (NGC) against Non-small Cell Lung Cancer (NSCLC), it was found the study that the $\mathrm{Cl}^{-}$ values $(<0.59)$ were suggestive of synergistic behavior i.e., NGC, Gem and noscapine treatments caused tumor volume reduction by $82.9 \%, 39.4 \%$ and $34.2 \%$ respectively. These results are suggestive of potential benefits for the use of NGC chemotherapy to treat lung cancer. An isoquinoline alkaloid, noscapine has the potential of antineoplastic or antimitotic activity [71]; thereby inhibiting the tumor cell growth by targeting tubulin which leads to an abnormal gathering of mitotic spindles [64]. Noscapine, an antitussive drug, has been previously shown to inhibit the growth of cultured tumor cells 
and tumors implanted in mice. Like some other antitumor agents, noscapine targets a cellular protein, tubulin, that is responsible for the assembly of important scaffolding polymers, microtubules. As a result, noscapine causes the aberrant assembly of the cellular machinery necessary for cell division, the mitotic spindle, which is followed by apoptotic cell death. Current evidence suggests that the antitumor activity of noscapine might lie in its initiation of apoptotic pathways. Compared with other microtubule drugs, noscapine has low toxicity and wide efficacy in animal models. For clinical use, noscapine affords simple means of administration including oral, rectal, parenteral, or by simple inhalation of suitable aerosols. Thus, noscapine and its analogs are potential cost-effective chemotherapeutic agents for the treatment of human cancers [64]. In a study performed on breast cancer cells, it was reported that morphine administered at the dose of 10,20 , and $30 \mathrm{mg} / \mathrm{kg}$ in the first, second, and third week respectively, inhibited the growth of tumor [82]. It has been shown that noscapine and papaverine-induced apoptosis and cytotoxic effects in cancerous cells while no apoptosis in normal cells was observed. Noscapine binds to the tubulin site of cancerous cells arresting the cell cycle; this phenomenon might describe the selective apoptosis of cancerous cells by noscapine. A minor increase in cytotoxicity of normal cells was observed which might be due to the non-selective cytotoxic effect of poppy seed alkaloids [83].

Other Physiological Effects: Poppy seed oil exhibits some striking features as it is a rich source of bioactive compounds including tocopherols, polysterols and essential fatty acids. Poppyseed oil is a valuable source of nutrition for PUFA and, if taken regularly, can increase the accumulation of essential fatty acids in the liver of healthy animals and at the same time has no negative effects on the animals [84]. A study investigated the influence of addition of poppy seed oil enriched with conjugated dienes of linoleic acid on cow and sheep milk composition like fatty acid profile, fatty content and atherogenic index. Milk from experimental animals exhibited higher levels of polyunsaturated fatty acids, trans-vaccenic acid and conjugated linoleic acid and decreased the atherogenic index [85]. Another study investigated the effect of dietary poppy seed oil on laying performance, reproduction, egg quality traits and fatty acid levels of egg yolk in the Japanese quail. Dietary supplementation of poppy seed oil caused the significant reduction in the saturated fatty acids and significant increase in unsaturated fatty acids of the egg yolk with no negative effects on the egg quality, laying performance and reproduction [23].

Poppy Seeds Applications In The Food Industry: Poppyseed and poppy seed oil do not contain a significant amount of alkaloid so can be used in different food products.

Application in bakery products: Poppy seeds can be incorporated in bakery products for flavoring and to increase the aesthetic value of the food products [19]. In many countries, poppy seeds are being used in confectionery and pastry making.

Animal fat is an important ingredient in biscuit manufacturing to maintain the texture, flavor and sensory profile of biscuits. The normal fat used in biscuit production comes from the animal source having high saturated fatty acid content. These fatty acids maintain the stability of the biscuits, but to avoid any undesirable health issues, lower levels of saturated fatty acids are desirable. The presence of 
high content of saturated fatty acids can cause severe health disorders including obesity, cancer, cholesterol and cardiac issues. To overcome these issues fat replacers can be used in biscuit manufacturing. The presence of phenolic compounds produces the antioxidant capacity in the product and reduces the auto-oxidation of fats and oils. The replacement of animal fat in biscuits with ground yellow poppy seed causes a significant increase in the phenolic content of biscuits. The total phenolic content increased after the fat replacement was from $0.89 \mathrm{mg}$ gallic acid/g to $1.22 \mathrm{mg}$ gallic acid/g sample. The overall results of three parameters showed that healthier biscuits can be obtained by the replacement of animal fat with edible vegetable oil from poppy seeds [86].

The effect of gluten-free bread enriched with poppy milk was examined to see the morphological, biochemical and antioxidant parameters in a ratbased in vivo study. Enriched bread has the potential to improve the antioxidant activity and reduce the triglyceride levels in rat's serum [87].

Application in the meat industry: The meat industry is studying the possibilities of using poppy seed oil as an animal fat replacer in those countries where consumption of meat is high [88]. The paste of ground poppy seed helps in lowering the level of saturated fatty acids and cholesterol as well as increasing the level of PUFAs, most importantly linoleic acid in meat burgers. When the poppy seed was added to the meat burgers the PUFA content increased from $2.51 \%$ to $46.43 \%$ [88].

Therefore, meat products containing animal fat are considered for causing hypertension, obesity, cardiovascular diseases and coronary health diseases. So, the use of poppy seed oil as a fat replacement in Turkish sucuk decreased cholesterol and saturated fatty acid content. Besides it, the addition of poppy seed oil increased the PUFAs which promote health benefits like lowering blood pressure and preventing coronary heart diseases. The sensory evaluation of poppy seed oil replaced food has shown good acceptability in sense of taste, color, flavor by the sensory evaluation panel [89].

Application in fats and oil industry: The oil which is obtained from the cold pressing is edible and used without any refining. This oil is used as raw material for the production of margarine [2][2]. Phenolic compounds present in poppy seed oil react with the reactive oxygen species produced in food processing and help to reduce rancidity in foods. They also help to increase the shelf life of the food products and to maintain the nutritive quality of foods as well [76]. A study demonstrated the use of poppy seeds as the enrichment ingredient in chocolate in replacement of hazelnuts. Hazelnut is a widely used ingredient in chocolates but proves an allergen for many people. Poppy seeds are added in varying concentrations in chocolates and results of the sensory evaluation indicated that most of the consumers like the poppy seed enrichment in chocolates. Chocolate incorporated with the $4 \%$ whole poppy seed exhibited the highest score in terms of all tested sensory parameters [90].

Application in flavors and seasonings: Poppy seeds are a good source of many amino acids including glycine, alanine, tyrosine, phenylalanine, aspartic acid. These amino acids impart specific flavors. Poppy seeds are crushed and used in many food items as seasonings to impart spices and specific flavors to food items [91]. A study showed that poppy oil contains many hydrocarbons, aldehydes, ketones, 
oxygenated aromatic compounds, organic and ester compounds which also impart specific aromas and flavors to different foods [92].

Application in the beverage industry: A study demonstrated the effect of different concentration techniques such as vacuum heating, microwave heating and conventional heating on phenolic, anthocyanin content and antioxidant activity of poppy sorbet, a traditional Turkish beverage. Poppy sorbet prepared by vacuum heating technique is an excellent source of total phenolic content (1022.84 $\mathrm{mg} \mathrm{GAE} / \mathrm{kg}$ ) and anthocyanin content (774.49 mg cyn$3-\mathrm{glu} / \mathrm{kg}$ ) in comparison to the other two methods. Poppy sorbet prepared by vacuum heating also exhibits excellent color properties and bioactivity [36]. Poppy seeds have also been used to develop poppy tea containing enough opioids to develop psychoactive effects [93].

\section{Application as a preservative against bacteria and}

lipid oxidation: Antibacterial activities of aqueous decoctions of poppy seeds were tested by Chaudhry and Tariq [78]. Poppyseed decoctions inhibited the growth of $14.4 \%$ of bacteria tested by the disc diffusion method. Poppyseed decoctions showed antimicrobial potential against Escherichia coli, Micrococcus roseus, Alcaligenes spp. and Citrobacter spp. This study explored how poppy seed decoctions can be used as a potential antibacterial agent in food products.

Kirkan, Ozer [94] explored the antioxidant and enzyme inhibitory effect on $\alpha$-amylase, $\alpha$ - glucosidase, cholinesterases and tyrosinase of extracts from the stalks of the poppy plant. Results showed that poppy plant extract can be an alternative source of antioxidant compounds in the food industry. Cibulkova, Certik [84] developed a methodology based on non-isothermal differential scanning calorimetry (DSC) to assess the oxidative stability of commercial poppy seeds. The results obtained showed that oxidative stability of poppy seeds at room temperature was two months while during thermal processing at $150^{\circ} \mathrm{C}$ it falls to a few minutes.

Functional properties of poppy seed: After the extraction of oil, poppy seed meal can be used as a source of vegetable proteins. Proteins extracted from the poppyseed meal exhibit good functional properties i.e., water holding capacity, viscosity, emulsification potential and whipping characteristics. It can also be used for the nutritional fortification of food products and to add textural and organoleptic characteristics to food products. An overview of the different functional properties of poppy seed is described in Table 4. 
Table 4. Functional properties of different varieties of poppy seed groups treated by roasted, enzyme treatment and control

\begin{tabular}{|c|c|c|c|c|c|c|c|c|c|c|}
\hline Fatty acids & $\begin{array}{l}\text { Bialek, } \\
\text { Bialek } \\
\text { [111] }\end{array}$ & $\begin{array}{l}\text { Carrión- } \\
\text { Prieto, Silva- } \\
\text { Castro [16] }\end{array}$ & $\begin{array}{l}\text { Lancaricová, } \\
\text { Havrlentová } \\
\text { [112] }\end{array}$ & $\begin{array}{l}\text { Rahimi, } \\
\text { Arslan [22] }\end{array}$ & $\begin{array}{l}\text { Aksoy } \\
\text { [113] }\end{array}$ & $\begin{array}{l}\text { Midilli, } \\
\text { Bayram } \\
{[23]}\end{array}$ & $\begin{array}{l}\text { Azcan, } \\
\text { Kalender } \\
{[73]}\end{array}$ & $\begin{array}{l}\text { Nergiz, } \\
\text { Ötles } \\
\text { [17] }\end{array}$ & $\begin{array}{l}\text { Hlinková, } \\
\text { Havrlentová } \\
\text { [114] }\end{array}$ & $\begin{array}{l}\text { Luhmer, } \\
\text { Schulze- } \\
\text { Kaysers [37] }\end{array}$ \\
\hline Amount & $(\%)$ & $(\%)$ & (\%) & $(\%)$ & (\%) & (\%) & (\%) & $(\%)$ & (\%) & (\%) \\
\hline $\begin{array}{c}\text { Palmitoleic } \\
\text { acid }\end{array}$ & - & - & - & $0.11-0.25$ & 0.13 & 0.10 & - & 0.15 & $0.33-0.39$ & $1.7-2.0$ \\
\hline Oleic acid & 1.1 & $4-11$ & $16-30$ & $13.30-17.80$ & 11.94 & 16.98 & $13.2-36.8$ & 12.83 & $15.39-16.80$ & $11.2-14.9$ \\
\hline $\begin{array}{l}\text { Linoleic } \\
\text { acid }\end{array}$ & 69.3 & 45 & $50-70$ & 72.55 & 74.47 & 71.73 & $41.0-68.0$ & 75.72 & $65.02-65.83$ & $70.7-75.2$ \\
\hline $\begin{array}{l}\text { Linolenic } \\
\text { acid }\end{array}$ & 0.7 & 2.7 & - & $0.55-0.75$ & 0.6 & 0.12 & - & 0.43 & $0.60-0.70$ & 0.66 \\
\hline $\begin{array}{l}\text { Stearic } \\
\text { acid }\end{array}$ & 13.9 & - & - & $1.84-2.40$ & 1.93 & 2.27 & - & 1.81 & 1.86 & - \\
\hline $\begin{array}{l}\text { Palmitic } \\
\text { acid }\end{array}$ & 10.0 & $8.6-10$ & $6-16$ & $7.96-10.19$ & 9.79 & 8.74 & $8.9-21.5$ & 8.64 & $15.13-15.55$ & $10.7-12$ \\
\hline $\begin{array}{l}\text { Arachidic } \\
\text { acid }\end{array}$ & 0.1 & - & - & $<0.20 \%$ & - & - & - & 0.37 & $0.07-0.08$ & - \\
\hline
\end{tabular}


Synthetic Opium Derivatives: Hydromorphon is prepared by catalytic reduction of morphine to dihydromorphine followed by oxidation and is 8 times more effective than morphine. Oxymorphone is prepared by strong acid $(\mathrm{HBr})$ demethylation of oxycodone and is 10 times more active than morphine. Thermal treatment of morphine with hydrochloric acid at $140{ }^{\circ} \mathrm{C}$ removes the water from morphine and transforms it into apomorphine hydrochloride. Hydrocodone can be prepared from thebain via acid catalyzed hydrolysis and hydrogenation. Hydrocodone has been proven to be a more effective antitussive agent than codeine. Oxycocdon is prepared by hydrogen peroxide oxidation of thebaine followed by acidic hydrolysis of resulting hydroxycodeinone. Oxycodone is used as an active sedative analgesic drug for the treatment of moderate to severe pain $[95,96]$.

Poppyseed Allergens: With the growing trend of using poppy seed in food products, hypersensitivity reactions to poppy seeds have been frequently occurring but rarely reported. Poppyseed can induce instant allergic reactions ranging from mild symptoms to severe anaphylactic reactions. Immunoglobulin Emediated allergies to poppy seeds are rare but if present can lead to severe clinical symptoms. Anaphylactic reaction characterized by clinical symptoms of itchiness around lips, nausea and dyspnea to poppy seed was reported by Wagner and Ring [97]. A case of atopic dermatitis was reported in a woman when eating ice cream with poppy seed topping [98]. Another case of poppy seed allergy was reported with the symptoms of epigastric pain and respiratory discomfort in a woman after eating a piece of poppy seed cake [99]. A very high crossreactivity among poppy seed, hazelnuts, rye grains and sesame seeds have been reported [100]. An oligopeptide of 45 kDa from poppy seed has been considered a major allergen. Sera of 9 out of 11 patients with poppy seed-induced adverse reactions showed binding with allergens [101]. A similar oligopeptide of $46 \mathrm{kDa}$ was found in a patient of anaphylaxis who developed adverse reactions within a few minutes after consumption of poppy seed [102].

Toxicity Induced By Poppy Seed: The sap of the opium poppy contains 80 different alkaloids such as morphine and codeine which have been used as pharmaceutical ingredients. Opium alkaloids are not naturally present in poppy seed but they can become contaminated with the sap of poppy plant during harvesting or due to pest damage. Morphine and codeine can be extensively absorbed from the gastrointestinal tract. Animal-based experimental studies have shown that morphine affects the nervous system and its development. Studies have demonstrated that thebaine and oripavine have more acute toxic effects than morphine. Oral administration of noscapine has shown lower acute toxicity than other opioid alkaloids. A toxic effect of thebaine may occur due to its conversion into morphine via metabolism [103]. Different studies have suggested that opium users have a high risk of developing coronary artery diseases $[104,105]$. The Panel on Contaminants in the Food Chain has reported that morphine-like adverse effects have been observed in consumers who consumed opium contaminated poppy seeds. The panel has also established an Acute Reference Dose (ARfD) of $10 \mu \mathrm{g}$ morphine per kg of body weight. Consumers of food products containing a large amount of poppy seeds are at risk of exceeding the ARfD. Different food 
processing techniques such as washing, cooking, grinding and soaking can be employed to reduce the opium alkaloid content.

Treatments to reduce narcotic alkaloid, morphine and codeine content from the poppy seeds: Morphine and codeine are considered as the narcotic alkaloids in poppy seed and intake of these alkaloids can cause drug abuse. The European Food Safety Authority (EFSA) has set the limit of opium alkaloids as $10 \mu \mathrm{g} / \mathrm{kg}$ of food [31]. Morphine is the major alkaloid which is needed to be reduced when the poppy seed is used for consumption. One of the methods to remove morphine content is washing, drying and grinding poppy seeds. Poppy seeds are washed with medium-hot water having a temperature of more than $60^{\circ} \mathrm{C}$ for a few minutes which reduces about $60 \%$ of the morphine contents and also improves the organoleptic properties of the poppy seeds. Fresh Grinding is also preferred to reduce the significant amount of morphine because already ground poppy seeds are prone to rancidity due to the presence of the unsaturated fatty acids [106]. Grinding is also a recommended method to reduce the alkaloid contents of poppy seeds. In the process of grinding, morphine is degraded in the presence of oxygen and converted into pseudomorphine and morphine-N-oxide. Opium alkaloids can also be extracted with methanol from seeds. The efficient extraction can be done using the combination of methanol with $0.1 \%$ acetic acid(v/v) and acetonitrile: formic acid: water in the ratio of 60:0.4:40 (v/v). There are many methods used for the rapid analysis of alkaloids in poppy seeds including liquid chromatography and mass spectrophotometry with the combination of dilute and shoot up approaches [31].
Sproll, Perz [107] proposed a correct treatment plan for consumers and bakers to reduce the morphine content of poppy seeds significantly using different treatments. They established a fact that treatments of poppy seeds such as washing with hot water, drying and grinding can reduce the morphine content by $70 \%$. If the poppy seeds are used in bakery products, then baking should be performed at the highest possible baking temperature as the higher baking temperature can significantly degrade the morphine content. A reduction of $30 \%$ in the morphine content of poppy seed was observed at $135^{\circ} \mathrm{C}$ baking temperature while at $220^{\circ} \mathrm{C}$ a reduction of $80-90 \%$ was observed [108]. Different interventions like washing, steam treatments and baking have also been employed in another study to reduce the opium alkaloids morphine, codeine and thebaine content of the poppy seed. Thebaine showed the greatest reduction in response to heat treatment, followed by morphine and then codeine. Water wash treatments, unlike steam treatments, were effective in reducing opium alkaloid levels. Experiments with muffins as a baked product model showed the stability of opium alkaloids, as these compounds were not significantly reduced after baking [109].

\section{CONCLUSION}

The current review has pointed to many important potential areas of application for the poppy plant as herbal medicine and food ingredients containing essential bioactive compounds. The presence of unsaturated fatty acid, especially linoleic acid makes this plant highly suitable for cooking purposes. However, there is a need to conduct a comparative evaluation of the cooking properties of poppy seed oil with traditional cooking oil. Among various potential 
bioactive compounds, its tocopherol contents are critically important for developing natural antioxidants for preserving oils and fats in the food industry. Furthermore, the seeds of the poppy plant have different inorganic minerals in them and calcium and phosphorus are present in large quantities among all plants. A future study is needed to explore the mineral profile, amino acid profile and their health and medicinal effects. However, there have been very scarce studies on its tocopherol contents evaluation and the same is true for its other phenolic compounds. Hence its application in foods and nutraceuticals is very limited owing to legal constraints with regards to its misuse in various parts of the world. Considering the global food security threat, it is recommended here that poppy seed cultivation should be encouraged for food production and bioactive compounds isolations. Research should be conducted specifically on exploiting its potential as a novel bioactive food ingredient.

List of Abbreviations: LC-MS/MS: Liquid Chromatography with tandem mass spectrometry, PUFAs: Polyunsaturated fatty acids, EFSA: European Food Safety Authority, DSC: Differential Scanning Calorimetry, TNBC: Triple-Negative Breast Cancer, NSCLC: Non-small Cell Lung Cancer, NGC: Noscapine and Gemcitabine Combination, GPCR: G ProteinCoupled Receptors, BIAs: Benzylisoquinoline alkaloid, HMG-CoA: 3-hydroxy-3-methyl-glutaryl-coenzyme A.

Author's contribution: NK and RSK conceived the idea of review. AA, AM. and SA participated in drafting the manuscript. NK, RSK and ZA reviewed the manuscript, and all authors were engaged in drafting and editing the review. All authors have read and approved the final manuscript.
Conflict of interest: None of the authors have a conflict of interest to declare.

\section{REFERENCES}

1. Sethi KL, Sapra RL, Gupta R, Dhindsa KS, Sangwan NK: Performance of poppy cultivars in relation to seed, oil and latex yields under different environments. Journal of the Science of Food and Agriculture 1990, 52(3): 30913. DOI: https://doi.org/10.1002/jsfa.2740520304

2. Bozan B,Temelli F: Extraction of poppy seed oil using supercritical $\mathrm{CO}_{2}$. Journal of Food Science 2003, 68(2):

422-26. DOI: https://doi.org/10.1111/j.13652621.2003.tb05688.x

3. Özcan MM, Atalay Ç,: Determination of seed and oil properties of some poppy (Papaver somniferum L.) varieties. Grasas y aceites 2006, 57(2): 169-74. DOI: https://doi.org/10.3989/gya.2006.v57.i2.33

4. Chouvy P-A, Opium: uncovering the politics of the poppy. Harvard University Press; 2010.

5. Kapoor L: Opium poppy: botany, chemistry, and pharmacology. CRC Press; 1995.

6. EFSA Panel on Contaminants in the Food Chain (CONTAM), Scientific Opinion on the risks for public health related to the presence of opium alkaloids in poppy seeds. EFSA Journal, 2011, 9(11):2405. https://doi.org/10.2903/j.efsa.2011.2405

7. Dang TTT, Onoyovwi A, Farrow SC, Facchini PJ: Biochemical genomics for gene discovery in benzylisoquinoline alkaloid biosynthesis in opium poppy and related species. Methods in enzymology, 2012, 515:231-266. https://doi.org/10.1016/B978-0$\underline{12-394290-6.00011-2}$

8. Singh M, Chaturvedi N, Shasany AK, Shukla AK: Impact of promising genotypes of Papaver somniferum $L$. developed for beneficial uses. In International Symposium on Papaver, 2011, 1036:29-41. 10.17660/ActaHortic.2014.1036.3

9. Labanca F, Ovesna J, and Milella L: Papaver somniferum L. taxonomy, uses and new insight in poppy alkaloid pathways. Phytochemistry Reviews 2018, 17(4): 853-71. https://doi.org/10.1007/s11101-018-9563-3

10. Lindner E: Structure activities and pharmacological properties of the opium alkaloids, in The chemistry and 
biology of isoquinoline alkaloids. Springer; 1985:38-46. DOI: 10.1007/978-3-642-70128-3_3

11. Schiff PJ: Opium and Its Alkaloids. American Journal of Pharmaceutical Education 2002, 66(2): 186-94.

12. Skalicky M, Hejnak V, Novak J, Hejtmankova A, and Stranska I: Evaluation of Selected Poppy (Papaver somniferum L.) Cultivars: Industrial Aspect. Turkish Journal of Field Crops 2014, 19(2): 89-96. DOI: https://doi.org/10.17557/tjfc.54263

13. Small E: Narcotic plants as sources of medicinals, nutraceuticals, and functional foods. In Proceedings of the international symposium on the development of medicinal plants. 2004: 24-25.

14. Hidalgo FJ, Zamora R: Peptides and proteins in edible oils: Stability, allergenicity, and new processing trends. Trends in Food Science and Technology 2006, 17(2): 56 63. DOI: https://doi.org/10.1016/j.tifs.2005.10.006

15. Bozan B, Temelli F: Chemical composition and oxidative stability of flax, safflower and poppy seed and seed oils. Bioresource Technology 2008, 99(14): 6354-59. DOI: https://doi.org/10.1016/j.biortech.2007.12.009

16. Carrión-Prieto P, Silva-Castro I, Ramos-Silva M, MartínRamos P, Martín-Gil J, Hernández-Navarro S: Vibrational analysis and thermal behavior of Salvia hispanica, Nigella sativa and Papaver somniferum seeds. Pharmacognosy Journal 2017, DOI: 10.5530/pj.2017.2.26

17. Nergiz C, Ötles S, The proximate composition and some minor constituents of poppy seeds. Journal of the Science of Food and Agriculture 1994, 66(2): 117-20. https://doi.org/10.1002/jsfa.2740660202

18. Srinivas H, Rao MNJJOA, Chemistry F: Studies on the proteins of poppy seed (Papaver somniferum L.) 1981. 29(6): 1232-35. https://doi.org/10.1021/jf00108a033

19. Emir D, Aydeniz DB, Yilmaz E: Effects of roasting and enzyme pretreatments on yield and quality of coldpressed poppy seed oils. Turkish Journal of Agriculture and Forestry 2015, 39(2): 260-71. Doi:10.3906/tar1409-34

20. Eklund A, Ågren G: Nutritive value of poppy seed protein. Journal of the American Oil Chemists' Society 1975, 52(6): 188-90. https://doi.org/10.1007/BF02672167

21. Vera G, Tatyana S, Elizaveta P, Aleksandra D, Larisa P, Aleksey K, Tamara Y, Natalya K, Andrey P, Nina B: The diversity of fatty acid composition in traditional and rare

oil crops cultivated in Russia. Biological Communications, 2020, 65(1):68-81. https://doi.org/10.21638/spbu03.2020.106

22. Rahimi A, Arslan N, Rezaeieh KaP, Gurbuz B. Variation in fatty acid composition of four turkish registered poppy (Papaver somniferum L.) seeds in two locations (Ankara and Boldavin) of Turkey. European Online Journal of Natural and Social Sciences 2015, 4(1): 183. https://www.researchgate.net/publication/289326619

23. Midilli M, Bayram I, Erol H, Cetingul IS, Cakir S, Calikoglu E, Kiralan M: The effects of dietary poppy seed oil and sunflower oil on performance, reproduction and egg quality parameters and fatty acid profile of egg yolk in the Japanese quail. Journal of Animal and Veterinary Advances. 2009, 8: 379-84.

24. Ghafoor K, Özcan MM, Al-Juhaimi F, Babiker EE, Fadimu GJ: Changes in quality, bioactive compounds, fatty acids, tocopherols, and phenolic composition in ovenand microwave-roasted poppy seeds and oil. LWT 2019, 99: 490-96. https://doi.org/10.1016/j.lwt.2018.10.017

25. Duke JA: Papaver somniferum L. Handbook of Energy Crops. 1983

26. Ivan S, Jozef FJAIEB: Content of heavy metals in poppy seeds (Papaver somniferum L.). 2011, 496-501.

27. Chalise U: The poppy plant: phytochemistry \& pharmacology. Indo Global Journal of Pharmaceutical Sciences, 2015, 5(1):58-65.

28. Mani D, Dhawan S.S. Scientific basis of therapeutic uses of opium poppy (Papaver somniferum) in Ayurveda. in International Symposium on Papaver, 2011:1036. DOI: 10.17660/ActaHortic.2014.1036.20

29. Kumaravel S, Alagusundaram K: Determination of mineral content in Indian spices by ICP-OES. Oriental journal of chemistry, 2014, 30(2):631-636.

30. Lachman J, Hejtmankova A, Miholova D, Kolihová D, Tluka P: Relations among alkaloids, cadmium and zinc contents in opium poppy (Papaver somniferum L.). Plant Soil and Environment, 2006, 52(6):282.

31. López P, Pereboom-de Fauw, DP, Mulder PP, Spanjer M, de Stoppelaar, J., Mol, H.G. and de Nijs, M: Straightforward analytical method to determine opium alkaloids in poppy seeds and bakery products. 2018, 242:443-450.

https://doi.org/10.1016/j.foodchem.2017.08.045 
32. Morimoto S, Suemori K, Moriwaki J, Taura F, Tanaka H, Aso M, Tanaka M, Suemune $H$, Shimohigashi $Y$, Shoyama Y: Morphine metabolism in the Opium Poppy and its possible physiological function: biochemical characterization of the morphine metabolite, bismorphine. Journal of Biological Chemistry, 2001, 276: 38179-38184.

DOI:https://doi.org/10.1074/jbc.M107105200

33. Luqman S: The saga of opium poppy: Journey from traditional medicine to modern drugs and nutraceuticals. in International Symposium on Papaver, 2011, 1036. DOI:10.17660/ActaHortic.2014.1036.9

34. Tang $Y$, Luan J, Zhang $X$ : Accelerating tissue expansion by application of topical papaverine cream. Plastic and reconstructive surgery, 2004, 114(5): 1166-1169. doi: 10.1097/01.PRS.0000135854.48570.76

35. Papas AM: Antioxidant status, diet, nutrition, and health. 2019: CRC press.

36. Ekici L: Effects of concentration methods on bioactivity and color properties of poppy (Papaver rhoeas L.) sorbet, a traditional Turkish beverage. LWT-Food Science and Technology, 2014, 56(1):40-48. https://doi.org/10.1016/j.Iwt.2013.11.015

37. Luhmer K, Schulze-Kaysers N, Feuereisen M, Wirth L, Maretzky F, Wüst M, Blum H, Dörr E, Pude R: Fatty Acid Composition, Tocopherols, Volatile Compounds, and Sensory Evaluation of Low Morphine Yielding Varieties of Poppy (Papaver somniferum L.) Seeds and Oils. 2021, Journal of Agricultural and Food Chemistry, 69(11):3439-3451. https://doi.org/10.1021/acs.jafc.0c07183

38. Rokosik E, Dwiecki K, Siger AJGYA: Nutritional quality and phytochemical contents of cold pressed oil obtained from chia, milk thistle, nigella, and white and black poppy seeds. Grasas y Aceites, 2020, 71(3):368.

39. Packer L, Weber SU, Rimbach GJTJON, Molecular aspects of $\alpha$-tocotrienol antioxidant action and cell signalling. 2001, 131(2): 369-373. https://doi.org/10.1093/jn/131.2.369S

40. Chin SF, Hamid NAA, Latiff AA, Zakaria Z, Mazlan M, Yusof YAM, Karim AA, Ibahim J, Hamid Z, Ngah WZW: Reduction of DNA damage in older healthy adults by Tri $E^{\circledR}$ Tocotrienol supplementation. Nutrition, 2008, 24(1):1-10. https://doi.org/10.1016/j.nut.2007.08.006
41. Parker RA, Pearce BC, Clark RW, Gordon DA, Wright JJ: Tocotrienols regulate cholesterol production in mammalian cells by post-transcriptional suppression of 3-hydroxy-3-methylglutaryl-coenzyme A reductase. Journal of Biological Chemistry, 1993, 268(15):1123011238.

DOI:https://doi.org/10.1016/S0021-9258(18)82115-9

42. Sen CK, Khanna S, Roy S: Tocotrienol: the natural vitamin $E$ to defend the nervous system?. Annals of the New York Academy of Sciences, 2004, 1031(1):127-142.

43. Chin KY, Tay SS: A review on the relationship between tocotrienol and Alzheimer disease. Nutrients, 2018, 10(7): 881. https://doi.org/10.3390/nu10070881

44. Montefusco A, Semitaio G, Marrese PP, lurlaro A, De Caroli M, Piro G, Dalessandro G, Lenucci MS: Antioxidants in varieties of chicory (Cichorium intybus L.) and wild poppy (Papaver rhoeas L.) of Southern Italy. Journal of Chemistry, 2015. https://doi.org/10.1155/2015/923142

45. Tétényi PJHR, Opium poppy (Papaver somniferum): botany and horticulture, 1997 19: 373-408.

46. Facchini PJ, Hagel JM, Liscombe DK, Loukanina N, MacLeod BP, Samanani N, Zulak KG: Opium poppy: blueprint for an alkaloid factory. Phytochemistry Reviews, 2007, 6(1): 97-124. DOI 10.1007/s11101-0069042-0

47. Weid M, Ziegler J, Kutchan TM: The roles of latex and the vascular bundle in morphine biosynthesis in the opium poppy, Papaver somniferum. Proceedings of the National Academy of Sciences, 2004, 101(38): 1395713962. https://doi.org/10.1073/pnas.0405704101

48. Facchini PJ, Park SU: Developmental and inducible accumulation of gene transcripts involved in alkaloid biosynthesis in opium poppy. Phytochemistry, 2003, 64(1): 177-186. https://doi.org/10.1016/S00319422(03)00292-9

49. Beaudoin GA, Facchini PJ: Benzylisoquinoline alkaloid biosynthesis in opium poppy. Planta, 2014, 240(1):1932. DOI 10.1007/s00425-014-2056-8

50. Memelink J: Putting the opium in poppy to sleep. Nature biotechnology, 2004, 22(12):1526-1527.

51. Calixto JB, Campos MM, Santos AR: Botanical analgesic and anti-inflammatory drugs. EthnopharmacologyVolume II, 2009: 36. 
52. Caraceni A, Hanks G, Kaasa S, Bennett MI, Brunelli C, Cherny N, Dale O, De Conno F, Fallon M, Hanna M, Haugen DF: Use of opioid analgesics in the treatment of cancer pain: evidence-based recommendations from the EAPC. The lancet oncology, 2012, 13(2):58-68. https://doi.org/10.1016/S1470-2045(12)70040-2

53. Luger NM, Mach DB, Sevcik MA Mantyh PW: Bone cancer pain: from model to mechanism to therapy. Journal of pain and symptom management, 2005, 29(5):32-46. https://doi.org/10.1016/j.jpainsymman.2005.01.008

54. Öztürk T, Karadibak K, Çatal D, Çakan A, Tugsavul F, Çırak $\mathrm{K}$ : Comparison of TD-fentanyl with sustained-release morphine in the pain treatment of patients with lung cancer. Agri, 2008, 20(3):20-25.

55. Heydari $M$, Hashem Hashempur $M$, Zargaran $A$ : Medicinal aspects of opium as described in Avicenna's Canon of Medicine. Acta medico-historica Adriatica, AMHA, 2013, 11(1):101-112.

56. Kalant $\mathrm{H}$ : Opium revisited: a brief review of its nature, composition, non-medical use and relative risks. Addiction 1997, 92(3): 267-277. DOI: https://doi.org/10.1111/j.1360-0443.1997.tb03197.x

57. Tedeschi LO, Muir JP, Naumann HD, Norris AB, RamírezRestrepo CA, Mertens-Talcott SU: Nutritional Aspects of Ecologically Relevant Phytochemicals in Ruminant Production. Frontiers in Veterinary Science, 2021, 8:155.

58. Paul D, Standifer KM, Inturrisi CE, Pasternak GW: Pharmacological characterization of morphine- 6 betaglucuronide, a very potent morphine metabolite. Journal of Pharmacology and Experimental Therapeutics 1989, 251(2): 477-83. https://jpet.aspetjournals.org/content/251/2/477.shor

59. Leppert W: The impact of opioid analgesics on the gastrointestinal tract function and the current management possibilities. Contemp Oncol (Pozn) 2012, 16(2): 125-31. DOI: 10.5114/wo.2012.28792

60. Snir N, Moskovitz B, Nativ O, Margel D, Sandovski U, Sulkes J, Livne PM, Lifshitz DA: Papaverine hydrochloride for the treatment of renal colic: an old drug revisited. A prospective, randomized study. The Journal of urology 2008, 179(4): 1411-1414. DOI: https://doi.org/10.1016/j.juro.2007.11.053
61. Ballantyne JC, LaForge SK: Opioid dependence and addiction during opioid treatment of chronic pain. Pain, 129(3), 2007:235-255. Doi: 10.1016/j.pain.2007.03.028

62. Chou R, Fanciullo GJ, Fine PG, Adler JA, Ballantyne JC, Davies P, Donovan MI, Fishbain DA, Foley KM, Fudin J, Gilson AM: Clinical guidelines for the use of chronic opioid therapy in chronic noncancer pain. The Journal of Pain, 2009, 10(2): 113-130. https://doi.org/10.1016/j.jpain.2008.10.008

63. Huxtable C, Roberts L, Somogyi A, Macintyre P: Acute pain management in opioid-tolerant patients: a growing challenge. Anaesthesia and intensive care 2011, 39(5): 804-823. DOI: https://doi.org/10.1177/0310057X1103900505

64. Joshi HC, Zhou J: Noscapine and analogues as potential chemotherapeutic agents. Drug News Perspect 2000, 13(9): 543-6.

65. Sultana S, Khan A, Safhi MM, Alhazmi HA: Cough Suppressant Herbal Drugs: A Review. International Journal of Pharmaceutical Science Invention 2016, 5(5): 15-28.

66. Schmeller T, Wink M: Utilization of alkaloids in modern medicine. In Alkaloids biochemistry ecology and medicinal applications. Edited by Roberts MF, Wink M. $\begin{array}{lll}\text { Springer } & \text { 1998, 435-59. }\end{array}$ https://doi.org/10.3389/fvets.2021.628445

67. Bolser DC, Hey JA, Chapman RW: Influence of central antitussive drugs on the cough motor pattern. Journal of Applied Physiology, 1999, 86(3): 1017-24. DOI: https://doi.org/10.1152/jappl.1999.86.3.1017

68. Simera M, Poliacek I, Jakus J: Central antitussive effect of codeine in the anesthetized rabbit. European Journal of Medical Research 2010, 15(2):1-5. https://link.springer.com/article/10.1186/2047-783X15-S2-184

69. Peters R, Jr., Yacoubian GS, Jr., Rhodes W, Forsythe KJ, Bowers KS, Eulian VM, Mangum CA, O'neal JD, Martin Q, Essien EJ. Beliefs and social norms about codeine and promethazine hydrochloride cough syrup (CPHCS) use and addiction among multi-ethnic college students. Journal of Psychoactive Drugs. 2007, 39(3): 277-282. DOI: https://doi.org/10.1080/02791072.2007.10400614

70. Mitich LW: Corn Poppy (Papaver rhoeas L.). Weed $\begin{array}{lll}\text { Technology } 2000, & 14(4): & 826-829 .\end{array}$ 
https://doi.org/10.1614/0890-

037X(2000)014[0826:CPPRL]2.0.CO;2

71. Mahmoudian M Rahimi-Moghaddam P: The anti-cancer activity of noscapine: a review. Recent Patents on Anticancer Drug Discovery 2009, 4(1): 92-97. DOI: https://doi.org/10.2174/157489209787002524

72. Winzer T, Gazda V, He Z, Kaminski F, Kern M, Larson TR, Li Y, Meade F, Teodor R, Vaistij FE, Walker C, Bowser TA, Graham IA: A Papaver somniferum 10-gene cluster for synthesis of the anticancer alkaloid noscapine. Science 2012, 336(6089): 1704-1708. DOI: 10.1126/science. 1220757

73. Azcan N, Kalender BO, Kara M: Investigation of Turkish poppy seeds and seed oils. Chemistry of Natural Compounds, 2004, 40(4): 370-372.

74. Bernath J: Poppy: the genus Papaver. CRC Press: 2003.

75. Robbers JE, Speedie MK, Tyler VE. Pharmacognosy and pharmacobiotechnology. Williams \& Wilkins: 1996.

76. Ishtiaque $\mathrm{S}$, Khan $\mathrm{N}$, Siddiqui MA, Siddiqi R, Naz S. Antioxidant Potential of the Extracts, Fractions and Oils Derived from Oilseeds. Antioxidants (Basel) 2013, 2(4) 246-56. DOI: https://doi.org/10.3390/antiox2040246

77. Manju V, Revathi R, Murugesan M: In vitro Antioxidant, Antimicrobial, Anti-inflammatory, Anthelmintic Activity and Phytochemical Analysis of Indian Medicinal Spices. Research Journal of Pharmacy and Technology 2011 4(4): 596-99.

78. Chaudhry NMA, Tariq P: In vitro antibacterial activities of kalonji, cumin and poppy seed. Pakistan Journal of $\begin{array}{lll}\text { Botany } & 2008, & 401\end{array}$ http://www.pakbs.org/pjbot/PDFs/40(1)/PJB40(1)461. pdf

79. Güler DA, Aydın A, Koyuncu M, Parmaksız İ: Anticancer Activity of Papaver Somniferum. Journal of the Turkish Chemical Society, Section A: Chemistry 2016, 3(3): 34966. DOI: https://doi.org/10.18596/jotcsa.43273

80. Sasamura T, Nakamura S, lida Y, Fujii H, Murata J, Saiki I, Nojima H, Kuraishi Y: Morphine analgesia suppresses tumor growth and metastasis in a mouse model of cancer pain produced by orthotopic tumor inoculation. European journal of pharmacology 2002, 441(3): 18591. DOI: https://doi.org/10.1016/S00142999(02)01450-4

81. Chougule MB, Patel AR, Jackson T, Singh M: Antitumor activity of Noscapine in combination with Doxorubicin in triple negative breast cancer. PLoS One 2011, 6(3): 17733.

DOI: https://doi.org/10.1371/journal.pone.0017733

82. Tegeder I, Grösch S, Schmidtko A, Häussler A, Schmidt H, Niederberger E, Scholich K, Geisslinger G: G proteinindependent $\mathrm{G} 1$ cell cycle block and apoptosis with morphine in adenocarcinoma cells: involvement of p53 phosphorylation. Cancer research 2003, 63(8): 1846-52. https://cancerres.aacrjournals.org/content/63/8/1846. short

83. Afzali $\mathrm{M}$, Ghaeli $\mathrm{P}$, Khanavi $\mathrm{M}$, Parsa $\mathrm{M}$, Montazeri $\mathrm{H}$, Ghahremani MH, Ostad SN: Non-addictive opium alkaloids selectively induce apoptosis in cancer cells compared to normal cells. DARU Journal of Pharmaceutical Sciences 2015, 23(1): 16. DOI 10.1186/s40199-015-0101-1

84. Fotschki B, Opyd P, Juśkiewicz J, Wiczkowski W, Jurgoński A: Comparative effects of dietary hemp and poppy seed oil on lipid metabolism and the antioxidant status in lean and obese zucker rats. Molecules, 2020, 25(12):2921

https://doi.org/10.3390/molecules25122921

85. Bodkowski R, Czyż K, Wyrostek A, Cholewińska P, Sokoła-Wysoczańska E, Niedziółka R: The effect of CLArich isomerized poppy seed oil on the fat level and fatty acid profile of cow and sheep milk. Animals, 2020, 10(5):912. https://doi.org/10.3390/ani10050912

86. Yalcin S: Determination of quality characteristic of biscuits including ground yellow poppy seed as fat replacer. International Journal of Secondary Metabolite 2017, 4(406-411).

DOI: https://doi.org/10.21448/ijsm.375105

87. Swieca M, Regula J, Suliburska J, Zlotek U, Gawlik-Dziki $U$. Effects of gluten-free breads, with varying functional supplements, on the biochemical parameters and antioxidant status of rat serum. Food Chemistry 2015, 182: $268-74$

DOI: https://doi.org/10.1016/j.foodchem.2015.03.014

88. Gok V, Akkaya L, Obuz E, Bulut S: Effect of ground poppy seed as a fat replacer on meat burgers. Meat Science 2011, 89(4): 400-044. DOI: https://doi.org/10.1016/j.meatsci.2011.04.032

89. Gok V: Effect of Replacing Beef Fat with Poppy Seed Oil on Quality of Turkish Sucuk. Korean Journal for Food 
Science of Animal Resources 2015, 35(2): 240-7. DOI: 10.5851/kosfa.2015.35.2.240

90. Zay K, Gere AJL: Sensory acceptance of poppy seedflavored white chocolates using just-about-right method. LWT 2019, 103: 162-68. DOI: https://doi.org/10.1016/j.lwt.2018.12.069

91. Guo J, Kong D, Hu L: Comparative analysis of volatile flavor compounds of poppy seed oil extracted by two different methods via gas chromatography/mass spectrometry. Journal of Pharma Science Techonology 2015, 4(2): 36-38. DOI: http://www.pharmascitech.in

92. Kopuncová M, Sádecká J, Kolek E, Havrlentová M, Blaško $\mathrm{J}$ : Key odour-active compounds in selected Slovakian poppy seed (Papaver somniferum L.) varieties revealed by gas chromatography-olfactometry. Journal of Food and Nutrition Research 2016, 55(3): 237-46.

93. Haber I, Pergolizzi J, LeQuang JA: Poppy Seed Tea: A Short Review and Case Study. Pain and Therapy, 2019. 8(1): 151-155. https://doi.org/10.1007/s40122-0190113-5

94. Kirkan B, Ozer MS, Sarikurkcu C, Copuroglu M, Cengiz M, Tepe B: Can the stalks of Papaver somniferum L. be an alternative source of bioactive components? Industrial crops and products 2018, 115: 1-5. DOI: https://doi.org/10.1016/j.indcrop.2018.02.023

95. Drugs Facts and Comparisons News, Facts and Comparisons, St Louis MO, 2001:65-66.

96. Cada DJ: Drug Facts and Comparisons, Facts and Comparisons. 2001.

97. Wagner G, Ring JJN: Anaphylaktische Reaktionen durch Nuss-und Mohnallergie. 1981, 7:694-696.

98. Kalyoncu A, Stålenheim G: Allergy to poppy seed. Allergy 1993, 48(4): 295-95.

99. Frantzen B, Bröcker EB, Trautmann A. Immediate-type allergy caused by poppy seed. Allergy 2000, 55(1): 97 98. DOI: 10.1034/j.1398-9995.2000.00456.x

100. Vocks E, Borga A, Szliska C, Seifert H, Seifert B, Burow G, Borelli S: Common allergenic structures in hazelnut, rye grain, sesame seeds, kiwi, and poppy seeds. Allergy 1993, 48(3): 168-72. DOI: 10.1111/j.13989995.1993.tb00732.x

101. Jensen-Jarolim E, Gerstmayer G, Kraft D, Scheiner O, Ebner $\mathrm{H}$, Ebner C: Serological characterization of allergens in poppy seeds. Clinical and experimental allergy: Journal of the British Society for Allergy and Clinical Immunology 1999, 29(8):1075-79.

102. Crivellaro M, Bonadonna P, Dama A, Senna G, Mezzelani $P$, Mistrello $G$, and Passalacqua $G$, Severe systemic reactions caused by poppy seed. Journal of Investigational Allergology and Clinical Immunology 1999, 9(1):58-59. PMID: 10212860

103. Chain EPOCITF, Knutsen HK, Alexander J, Barregård L, Bignami M, Brüschweiler B, Ceccatelli $S$, Cottrill B, Dinovi M, Edler L: Update of the Scientific opinion on opium alkaloids in poppy seeds. EFSA Journal 2018, 16(5): 05243.

DOI: https://doi.org/10.2903/j.efsa.2018.5243

104. Masoomi M, Ramezani MA, Karimzadeh H: The relationship of opium addiction with coronary artery disease. International Journal of Preventive Medicine 2010, 1(3): 182. PMID: 21566789

105. Masoumi M, Shahesmaeili A, Mirzazadeh A, Tavakoli M, Ali AZ: Opium addiction and severity of coronary artery disease: a case-control study. Journal of research in medical sciences: the official journal of Isfahan University of Medical Sciences 2010, 15(1): 27. PMID: $\underline{21526055}$

106. Margasahayam A, Balraj YJJOFPE: Properties of food ingredients during processing in a domestic mixer grinder and subsequent storage: A review. Journal of Food Process Engineering 2018, 41(4): 12677. DOI: https://doi.org/10.1111/jfpe.12677

107. Sproll, C., et al., Guidelines for reduction of morphine in poppy seed intended for food purpose 2007, 226(1): p. 307-310

108. Sproll C, Perz RC, Lachenmeier DW: Optimized LC/MS/MS analysis of morphine and codeine in poppy seed and evaluation of their fate during food processing as a basis for risk analysis. Journal of Agricultural and Food Chemistry 2006, 54(15): 5292-98. DOI: https://doi.org/10.1021/jf0608975

109. Shetge SA, Dzakovich MP, Cooperstone JL, Kleinmeier D, Redan BW:Concentrations of the opium alkaloids morphine, codeine, and thebaine in poppy seeds are reduced after thermal and washing treatments but are not affected when incorporated in a model baked product. Journal of Agricultural and Food Chemistry 2020, 68(18):5241-5248. https://doi.org/10.1021/acs.jafc.0c01681 
110. Peter KV: Handbook of herbs and spices. Elsevier; 2012.

111. Bialek A, Bialek M, Jelinska M, Tokarz A: Fatty acid composition and oxidative characteristics of novel edible oils in Poland. CyTA-Journal of Food 2017, 15(1):1-8.

https://doi.org/10.1080/19476337.2016.1190406

112. Lancaricová A, Havrlentová M, Muchová D, Bednárová A: Oil content and fatty acids composition of poppy seeds cultivated in two localities of Slovakia. Agriculture 2016, 62(1):19. DOI: 10.1515/agri-2016-0003

113. Aksoy L: Opium poppy (Papaver somniferum L.) oil for preparation of biodiesel: Optimization of conditions. Applied Energy 2011， 88(12):4713-4718. https://doi.org/10.1016/j.apenergy.2011.06.012
114. Hlinková A, Havrlentová M, Šupová J, Bednárová A: Poppy seed (Papaver somniferum L.): effect of genotype and year of cultivation on variability in its lipid composition. Journal of Microbiology, Biotechnology and Food Sciences 2021: 908-922.

115. Yılmaz E, Emir DD: Compositional and functional characterisation of poppy seed (Papaver somniferum L.) press cake meals. Quality Assurance and Safety of Crops \& Foods 2017, 9(2):141-151. https://doi.org/10.3920/QAS2016.0863

116. Yilmaz E, Emir DD: Extraction and functional properties of proteins from pre-roasted and enzyme treated poppyseed (Papaver somniferum L.) press cakes. Journal of oleo science 2016: 15228. https://doi.org/10.5650/jos.ess15228 